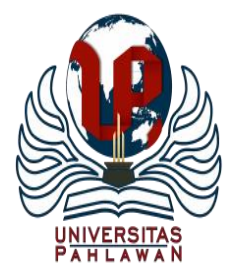

Edukatif : Jurnal Ilmu Pendidikan Volume 3 Nomor 3 Tahun 2021 Halm 900 - 910 EDUKATIF: JURNAL ILMU PENDIDIKAN

Research \& Learning in Education

https://edukatif.org/index.php/edukatif/index

\title{
Analisis Kesulitan Belajar Mahasiswa Secara Online (E-Learning) Selama Masa Pandemi Covid-19
}

Muhammad Turmuzi ${ }^{1 凶}$, Arifman S. Haji Dasing ${ }^{2}$ Baidowi $^{3}$, Junaidi $^{4}$

Pendidikan Matematika FKIP Universitas Mataram, Indonesia ${ }^{1,2,3,4}$

E-mail : tur.muzi@yahoo.co.id ${ }^{1}$, $\underline{\text { baidowiunram@gmail.com }}^{3}$, junaidi88@ unram.ac.id $^{4}$

\begin{abstract}
Abstrak
Tujuan penelitian ini adalah untuk menguraikan permasalahan yang dihadapi mahasiswa pendidikan matematika FKIP Universitas Mataram selama proses pembelajaran secara online serta untuk mengaitkan antara gambaran nyata terkait kesiapan mahasiswa dalam beradaptasi pada pembelajaran terhadap hasil belajar mahasiswa. Penelitian ini menggunakan metode deskriptif kualitatif. Jumlah responden yang diteliti dalam penelitian ini adalah 53 responden yang terdiri dari mahasiswa aktif pendidikan matematika FKIP Universitas Mataram angkatan 2018/2019. Sampel yang diambil menggunakan teknik Proportional Stratification Sampling. Teknik pengumpulan data menggunakan teknik angket. Teknik analisis data meliputi data reduction, penyajian data dan penarikan kesimpulan. Kesimpulan penelitian ini adalah terdapat berbagai macam kesulitan yang dihadapi oleh mahasiswa Pendidikan Matematika FKIP Universitas Mataram selama pembelajaran secara online. Adapun kesulitan dalam proses pembelajaran online yang di alami oleh mahasiswa terletak pada efektifitas proses belajar mengajar dan juga faktor kendala teknis seperti jaringan internet yang tidak stabil, kuota yang terbatas dan juga Interaksi yang minim ketika proses pembelajaran online berlangsung.
\end{abstract}

Kata Kunci: kesulitan belajar, pembelajaran Online, covid-19.

\begin{abstract}
The purpose of this study was to describe the problems faced by mathematics education students of the FKIP University of Mataram during the online learning process and to link the real picture related to students' readiness to adapt to student learning outcomes. This study used descriptive qualitative method. The number of respondents studied in this study were 53 respondents consisting of active students of mathematics education at the Faculty of Teacher Training and Education, Mataram University, class of 2018/2019. Samples were taken using the Proportional Stratification Sampling technique. The data collection technique used a questionnaire technique. Data analysis techniques include data reduction, data presentation and drawing conclusions. The conclusion of this study is that there are various kinds of difficulties faced by Mathematics Education students of the FKIP University of Mataram during online learning. The difficulties in the online learning process that students experience lies in the effectiveness of the teaching and learning process and also technical constraints such as unstable internet networks, limited quotas and also minimal interaction when the online learning process takes place.
\end{abstract}

Keywords: learning difficulties, online learning, covid-19.

Copyright (c) 2021 Muhammad Turmuzi, Arifman S. Haji Dasing, Baidowi, Junaidi

$\triangle$ Corresponding author

Email : tur.muzi@yahoo.co.id

DOI $\quad$ : https://doi.org/10.31004/edukatif.v3i3.482

ISSN 2656-8063 (Media Cetak)

ISSN 2656-8071 (Media Online)

Edukatif : Jurnal Ilmu Pendidikan Vol 3 No 3 Tahun 2021

p-ISSN 2656-8063 e-ISSN 2656-8071 
901 Analisis Kesulitan Belajar Mahasiswa Secara Online (E-Learning) Selama Masa Pandemi Covid-19Muhammad Turmuzi, Arifman S. Haji Dasing, Baidowi, Junaidi

DOI: https://doi.org/10.31004/edukatif.v3i3.482

\section{PENDAHULUAN}

Sejak merebaknya pandemi virus korona di Indonesia, pemerintah telah melakukan banyak langkah untuk mencegah penyebarannya. Salah satunya melalui surat edaran yang dikeluarkan Kementerian Pendidikan dan Kebudayaan (Kemendikbud) Biro Pendidikan Tinggi Nomor 1 Tahun 2020, perihal pencegahan penyebaran penyakit virus Corona (Covid-19) di perguruan tinggi. Melalui surat edaran ini, Kementerian Pendidikan dan Kebudayaan memberikan panduan pengajaran jarak jauh untuk universitas dan menyarankan mahasiswa untuk belajar di rumah mereka.(Firman \& Rahayu, 2020, p. 82). Untuk mencegah penyebaran Covid-19, WHO merekomendasikan untuk menghentikan sementara aktivitas yang dapat menyebabkan keramaian. Untuk itu perlu dilaksanakan pembelajaran rutin dimana banyak mahasiswa berkumpul di dalam kelas. Pembelajaran harus dilakukan dalam suasana yang meminimalkan kontak fisik antara mahasiswa dengan mahasiswa lain atau antara mahasiswa dan dosen. Menurut (Sadikin \& Hamidah, 2020) penggunaan teknologi digital memungkinkan mahasiswa dan dosen ditempatkan di tempat yang berbeda selama proses pembelajaran. Salah satu alternatif bentuk pembelajaran yang bisa dilakukan selama masa darurat Covid-19 adalah pembelajaran secara online (e-learning). E-learning merupakan teknologi informasi dan komunikasi yang memungkinkan mahasiswa untuk belajar kapanpun, dimanapun.(Hartanto, 2016). Menurut (Utami \& Cahyono, 2020, p. 21) e-learning adalah sistem pembelajaran yang dapat digunakan sebagai sarana untuk proses belajar mengajar yang dilakukan tanpa harus berhadapan muka langsung antara dosen dan mahasiswa.

Keberlangsungan pendidikan selama pandemi akan tergantung pada berbagai faktor, seperti tingkat persiapan kampus, kesiapan orang tua, dan kesiapan tenaga pengajar. Pertimbangan harus diberikan pada kebutuhan semua mahasiswa untuk terus memberikan pendidikan selama pandemi. Selain menggunakan hardcopy dari bahan pengajaran, seperti buku, buku kerja, dan dokumen lain yang dikirim melalui pos atau kurir, sekolah dapat menggunakan berbagai solusi berbasis teknologi untuk meningkatkan kemungkinan mahasiswa dapat melanjutkan kegiatan pembelajaran mereka. (Yunitasari \& Hanifah, 2020, p. 234). Perkembangan teknologi informasi dan komunikasi yang cepat mendorong keberagaman Institusi pendidikan menggunakan sistem e-learning untuk meningkatkan efektivitas dan Fleksibilitas belajar. Meski hasilnya banyak penelitian menunjukkan keefektifannya gunakan sistem e-learning untuk belajar seringkali sama dibandingkan dengan belajar konvensional atau klasik, tetapi kelebihannya dalam hal ini melalui $e$-learning fleksibilitas. Melalui materi e-learning bisa berkunjung dan belajar kapanpun, dimanapun di mana saja kecuali materi bisa memperkaya berbagai sumber belajar, termasuk Multimedia dapat dengan cepat diperbarui.(Noveandini \& Wulandri, 2010, p. 71).

Layanan edukasi online biasanya dilakukan dengan menggunakan berbagai aplikasi, seperti zoom, Google Classroom, webex meeting. Dapat digunakan sesuai kebutuhan pribadi. Aplikasi ini dirancang untuk mendistribusikan bahan ajar kepada mahasiswa. Keunggulan aplikasi ini tetap memberikan kesempatan untuk menghubungkan dosen dan mahasiswa, meski sedang online. Google Classrom merupakan model pembelajaran gabungan yang tujuan pengembangannya untuk mempermudah distribusi pembelajaran. Layanan berbasis internet ini dirancang dengan sistem e-learning untuk dosen dan dapat berbagi materi secara paperless. Harapannya melalui pemanfaatan teknologi dalam pembelajaran, penyampaian pembelajaran dapat dijamin secara efektif. (Marbun, 2021, p. 130). Menurut (Pujiasih, 2020, p. 44) pembelajaran online menggunakan aplikasi zoom, Jitzi, Google Class Meet, WebEx, membuat penjelasan singkat video yang dapat dibagikan dengan rekaman WhatsApp, YouTube dan video yang dapat digunakan media ini berulang kali. Dalam hal ini guru diharuskan untuk dapat menggunakan teknologi untuk digunakan dalam pembelajaran dan memerlukan fasilitas seluler atau gadget yang mendukung pembelajaran online dan dapat menggunakannya dan dapat dihubungkan ke Internet. 
902 Analisis Kesulitan Belajar Mahasiswa Secara Online (E-Learning) Selama Masa Pandemi Covid-19Muhammad Turmuzi, Arifman S. Haji Dasing, Baidowi, Junaidi

DOI: https://doi.org/10.31004/edukatif.v3i3.482

Zoom adalah aplikasi yang menggabungkan konferensi video, rapat online, obrolan, ke kolaborasi seluler untuk menyediakan layanan konferensi jarak jauh. Zoom dapat menyajikan kelas virtual sehingga dosen dan mahasiswa dapat berhadapan secara virtual, melaksanakan proses belajar dua arah dan memiliki efektivitas yang sama dengan pembelajaran tatap muka langsung. Inilah yang membuat aplikasi ini banyak digunakan sebagai alat belajar mengajar. Aplikasi lain yang biasa digunakan untuk pembelajaran online adalah Google Classroom yang secara resmi diluncurkan pada Agustus 2014. Google Classroom adalah aplikasi yang dapat membuat ruang kelas online sehingga dapat menjadi media untuk memberikan materi, mendistribusikan dan melakukan penilaian yang telah terjadi dikumpulkan oleh mahasiswa. Selain itu, Google Classroom menyediakan fitur untuk mengunggah video atau menautkan tautan video dari YouTube dan memiliki forum diskusi sehingga dosen dapat membuka diskusi kelas seperti di facebook yang dapat ditanggapi dan dikomentari. Kholis dan Kusuma dalam (Maulana, 2021, p. 189).

Dalam pelaksanaan kuliah secara online tidak terlepas dari kendala dan juga kesulitan, seperti yang diungkapkan oleh Jirana dan Rusman dalam (Noviati, 2020, p. 8) proses kuliah secara online ini tentu saja banyak kesulitan yang dihadapi oleh mahasiswa, ini dapat dilihat dari beberapa mahasiswa yang tidak mengikuti proses kuliah sehingga pendidik tidak dapat memonitor dan ini juga memiliki dampaknya pada hasil belajar mahasiswa. Keberhasilan proses pembelajaran dapat dilihat dari prestasi belajar yang dicapai oleh mahasiswa. Ini adalah dilema bagi para pendidik untuk dapat mengimplementasikan kuliah online. Jika dibandingkan dengan kuliah biasa, hasil belajar mahasiswa lebih baik. Pendidik harus dapat membantu kesulitan yang dihadapi oleh mahasiswa dalam proses pembelajaran. Hal yang sama juga terjadi di Program Studi Pendidikan Matematika FKIP Universitas Mataram. Mulai Maret 2020 Universitas Mataram telah menerapkan belajar dari rumah untuk mengganti tatap muka di kelas. Kebijakan belajar dari rumah mengharuskan dosen dan mahasiswa di FKIP Universitas Mataram untuk melakukan pembelajaran online sebagai pengganti alternatif untuk berhadapan muka. Tujuan penelitian adalah untuk menguraikan permasalahan yang dihadapi mahasiswa Pendidikan Matematika FKIP Universitas Mataram selama proses pembelajaran secara online serta untuk mengaitkan antara gambaran nyata terkait kesiapan mahasiswa dalam beradaptasi pada pembelajaran terhadap hasil belajar mahasiswa.

Perkuliahan di FKIP Universitas Mataram menerapkan kelas-kelas virtual menggunakan layanan Google Classroom, Daring Unram, Zoom, google meet dan aplikasi pesan instan seperti WhatsApp. Akan tetapi perubahan penggunaan model pembelajaran dari tatap muka secara langsung menuju ke arah pembelajaran e-learning yang terlalu tiba-tiba ini berdampak pada menurunnya minat dan hasil belajar mahasiswa dalam mengikuti pembelajaran. Hal ini dikarenakan tidak sedikit dari mahasiswa yang mengalami kesulitan dalam beradaptasi dengan model pembelajaran yang baru. Terutama untuk mahasiswa pendidikan matematika yang merasakan sekali dampak dari pembelajaran online ini. Untuk beberapa mata kuliah yang melibatkan proses berhitung seperti Aljabar Abstrak, kalkulus, Program linier dan lain-lain mahasiswa mangalami kesulitan dalam memahami mata kuliah tersebut. Hal ini dikarenakan biasanya mahasiswa langsung melihat cara dosen menjelaskan secara langsung di papan tulis namun hal tersebut jarang diaplikasikan ketika proses pembelajaran secara online.

Penelitian terkait kesulitan belajar mahasiswa pada masa covid-19 masih minim dibahas, akan tetapi penelitian lebih banyak membahas tentang motivasi belajar, gaya belajar dan aktivitas belajar selama masa pandemi covid-19, seperti penelitian oleh Hasanah et al. (2020) berkaitan dengan aktivitas belajar menyimpulkan bahwa spirit belajar, literasi akan teknologi pembelajaran daring, aktivitas komunikasi intrapersonal, aktivitas berkolaborasi, dan kemandirian belajar rata-rata berjalan dengan cukup baik. Penelitian oleh Fitriyani et al. (2020) membahas tentang motivasi belajar mahasiswa selama masa covid-19, penelitian oleh (Anggrawan, 2019) tentang pembelajaran daring menurut gaya belajar mahasiswa. Penelitian lain terkait kesulitan belajar selama masa covid-19 hanya terfokus pada satu mata kuliah seperti penelitian oleh Kumalasari \& Sugiman (2015) membahas kesulitan belajar mahasiswa di masa covid-19 pada mata kuliah 
Kapita Selekta Matematika Sekolah Menengah, Monariska (2019) membahas kesulitan belajar di masa pandemi covid-19 pada mata materi Integral. Oleh karena itu peneliti mengadakan penelitian lanjutan terkait kesulitan belajar mahasiswa selama masa pandemi covid-19 dengan populasi dan sampel yang lebih besar.

Salah satu permasalahn yang dihadapi dunia pendidikan secara spesifik di masa pandemi covid-19 mengharuskan semua pendidik baik guru maupun dosen melakukan kegiatan mengajar dari rumah. Munculnya istilah-istilah seperti work from home (WFH), study at home, dan teach from home menjadi familiar ditelinga kita, sebabnya pemerintah telah membuat aturan dan ketentuan bahwa semua kegiatan pendidikan tidak lagi dilakukan di sekolah atau kampus, melainkan dari rumah secara online. (Marbun, 2021, p. 129). Wabah pademic covid-19 telah mengubah kebiasaan-kebiasan dengan melakukan berbagai protokol kesehatan sepeti social distancing, phisycal distancing, cuci tangan, memakai masker dan lain-lain. Dunia pendidikan pun mengalami perubahan yang sangat besar, para guru dan dosen tidak lagi melakukan tugasnya di kelas-kelas pembelajaran melainkan berbasis daring (online). Menurut Darmalaksana et al. (2020, p. 2) pendidikan tinggi pada masa WFH perlu melakukan penguatan pembelajaran secara daring. Tetapi kenyataanya yang terjadi di Program Studi Pendidikan Matematika FKIP Universitas Mataram saat belajar secara online banyak kesulitan dan kendala yang dialami mahasiswa, mereka perlu beradaptasi dari pembelajaran tatap muka menjadi pembelajaran secara online, dan hal ini tidak mudah bagi mereka untuk mengubah kebiasaan belajar mereka. Asumsi awal penyebab kesulitan mahasiswa adalah terkait dengan penjelasan materi terutama materi perkuliahan yang mereka anggap sulit, gangguan jaringan akibat tempat tinggal mereka yang terpencil, serta kuota internet yang masih minim. Untuk mengeksplore lebih mendalam terkait kesulitan belajar mahasiswa selama masa pandemi covid-19 maka perlu kiranya diadakan penelitian lebih lanjut terkait kesulitan belajar mahasiswa secara online.

\section{METODE}

Penelitian ini menggunakan metode deskriptif kualitatif. dimana peneliti ditempatkan sebagai instrumen kunci. Dasar pemikiran digunakannya metode ini adalah karena penelitian ini ingin mengetahui tentang fenomena yang ada dan dalam kondisi yang alamiah, bukan dalam kondisi terkendali, labolatoris atau eksperimen. Teknik pengumpulan data pada penelitian ini adalah dengan Teknik angket, yang terdiri pertanyaan-pertanyaan terkait dengan kesulitan mahasiswa dalam pembelajaran online. Angket diberikan secara online melalui google formulir dan disebar melalui WhatsApp mahasiswa. Kisi-kisi angket dapat dilihat pada tabel 1 .

Tabel 1. Kisi-kisi Pertanyaan Dalam Angket

\begin{tabular}{|c|l|l|}
\hline No & \multicolumn{1}{|c|}{ Aspek yang Dinilai } & Tanggapan \\
\hline 1 & $\begin{array}{l}\text { Posen melakukan pembelajaran online melalui } \\
\text { - Zoom }\end{array}$ & \\
& $\begin{array}{c}\text { - Google Meet } \\
\text { - Google Classroom }\end{array}$ & \\
\hline 2 & $\begin{array}{l}\text { Materi yang disampaikan Dosen secara online } \\
\text { mudah dipahami }\end{array}$ & $\begin{array}{l}\text { Ya ( ) } \\
\text { Tidak ( ) }\end{array}$ \\
\hline 3 & $\begin{array}{l}\text { Durasi waktu pembelajaran online sesuai dengan } \\
\text { kebutuhan mahasiswa }\end{array}$ & $\begin{array}{l}\text { Ya ( ) } \\
\text { Tidak ( ) }\end{array}$ \\
\hline 4 & $\begin{array}{l}\text { Dosen-dosen memberikan feedback dalam diskusi } \\
\text { online }\end{array}$ & $\begin{array}{l}\text { Ya ( ) } \\
\text { Tidak ( ) }\end{array}$ \\
\hline
\end{tabular}




\begin{tabular}{|c|l|l|}
\hline 5 & $\begin{array}{l}\text { Jaringan internet stabil ketika pembelajaran online } \\
\text { berlangsung }\end{array}$ & $\begin{array}{l}\text { Ya ( ) } \\
\text { Tidak ( ) }\end{array}$ \\
\hline 6 & $\begin{array}{l}\text { Lingkungan tempat tinggal mendukung proses } \\
\text { pembelajaran secara online }\end{array}$ & $\begin{array}{l}\text { Ya ( ) } \\
\text { Tidak ( ) }\end{array}$ \\
\hline 7 & $\begin{array}{l}\text { Kuota internet memadai untuk melakukan } \\
\text { pembelajaran secara online }\end{array}$ & $\begin{array}{l}\text { Ya ( ) } \\
\text { Tidak ( ) }\end{array}$ \\
\hline 8 & $\begin{array}{l}\text { Interaksi antara mahasiswa efektif selama } \\
\text { pembelajaran online }\end{array}$ & $\begin{array}{l}\text { Ya ( ) } \\
\text { Tidak ( ) }\end{array}$ \\
\hline 9 & $\begin{array}{l}\text { Mahasiswa mampu beradaptasi terhadap } \\
\text { pembelajaran online }\end{array}$ & $\begin{array}{l}\text { Ya ( ) } \\
\text { Tidak ( ) }\end{array}$ \\
\hline
\end{tabular}

Teknik analisis data yang digunakan dalam penelitian ini adalah tekhnik analisis data kualitatif dengan menggunakan model Miles and Huberman (Simanjuntak \& Harahap, 2020, p. 143) meliputi tiga komponen, yaitu: 1). Data reduction (reduksi data), 2). Data display (penyajian data), dan 3). Conclusion drawing (penarikan simpulan). Sedangkan responden dalam penelitian ini adalah Mahasiswa Program Studi Matematika Fakultas Keguruan dan Ilmu Pendidikan Universitas Mataram yang masih aktif. Subjek penelitian dipilih berdasarkan teknik proportional stratification sampling. Proportional stratification sampling adalah teknik pengambilan sampel yang dapat mewakili setiap kelompok responden secara proporsional sehingga sampel menjadi representatif (Febriaty, 2018, p. 107). Mahasiswa Pendidikan matematika terdiri dari beberapa kelas, kemudian masing masing kelas akan dipilih perwakilan secara proporsional. Sampel yang dipilih kemudian di berikan instrumen.

\section{HASIL DAN PEMBAHASAN}

Jenis data yang digunakan dalam penelitian ini adalah data primer yang diperoleh dari hasil jawaban responden (mahasiswa) dengan mengisi angket yang dibagikan melalui google form. Dalam penelitian ini yang menjadi responden adalah mahasiswa aktif pendidikan matematika FKIP Universitas Mataram angkatan 2018 dan 2019 dengan jumlah sampel sebanyak 53 mahasiswa. Deskripsi data hasil penelitian akan disajikan sesuai dengan urutan masalah yang menjadi fokus penelitian dari hasil pengumpulan data melalui angket yang telah digunakan oleh peneliti. Data deskripsi yang dimaksud adalah data hasil angket. Pada tahap ini, peneliti menyebar angket terkait kesulitan yang dihadapi mahasiswa pendidikan matematika FKIP Universitas Mataram dalam pembelajaran online selama masa pandemi Covid-19. Berdasarkan hasil angket yang disebar terdapat beberapa faktor kesulitan yang dihadapi oleh mahasiwa yakni terkait proses belajar mengajar secara online yang diberikan oleh dosen dan faktor kendala teknis yang terjadi ketika proses kuliah secara online sedang berlangsung. Berikut adalah tabel jumlah proporsi sampel data mahasiswa.

Tabel 2. Jumlah Proporsi Sampel Data Mahasiswa

\begin{tabular}{|c|c|c|}
\hline \multicolumn{3}{|c|}{$\begin{array}{c}\text { Jumlah Proporsi Sampel Data Mahasiswa Aktif Pendidikan Matematika } \\
\text { FKIP Universitas Mataram }\end{array}$} \\
\hline Angakatan & Jumlah & Sampel \\
\hline 2018 & 163 & 33 \\
\hline 2019 & 102 & 20 \\
\hline Jumlah & 265 & 53 \\
\hline
\end{tabular}

Secara umum mahasiswa pendidikan Matematika FKIP Universitas Mataram melakukan pembelajaran daring melalui berbagai platform pembelajaran daring yang tersedia seperti zoom, google meet, daring unram, dan google classroom. Hal ini dapat dilihat berdasarkan angket yang dijawab oleh responden pada gambar 1 di bawah. 


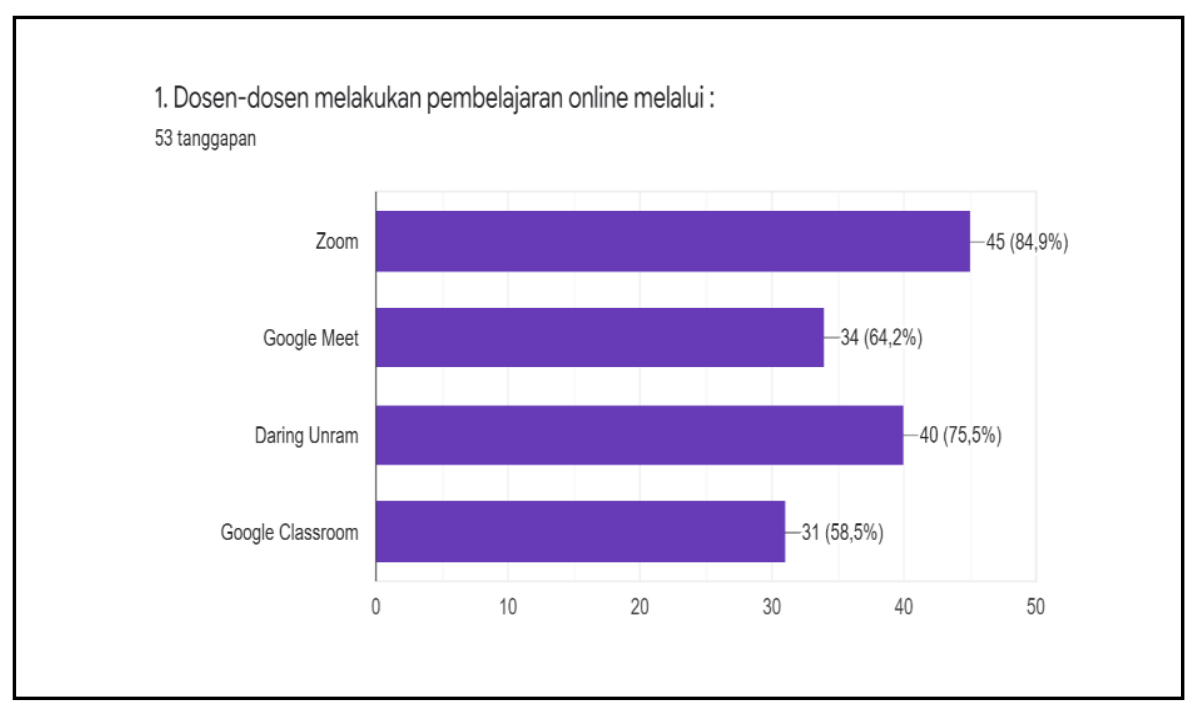

Gambar 1 : Platform Pembelajaran Online

Pada gambar 1 di atas dapat dilihat persentase penggunaan platform pembelajaran online Zoom sebanyak 84,9\%, Google Meet sebanyak 64,2\%, Daring Unram sebanyak 75,5\%, dan Google Classroom sebanyak $58,5 \%$. Deskripsi data hasil penelitian akan disajikan sesuai dengan urutan masalah yang menjadi fokus penelitian dari hasil pengumpulan data melalui teknik angket yang telah digunakan oleh peneliti. Data deskripsi yang dimaksud adalah sebagai berikut:

Tabel 3. Persentase Hasil Jawaban Angket

\begin{tabular}{|c|l|c|c|}
\hline \multirow{2}{*}{ No } & \multicolumn{1}{|c|}{ Pertanyaan Angket } & Persentase Jawaban \\
\cline { 2 - 4 } & $\begin{array}{l}\text { Materi yang disampaikan Dosen secara online } \\
\text { mudah dipahami }\end{array}$ & $49,1 \%$ & $50,9 \%$ \\
\hline 2 & $\begin{array}{l}\text { Durasi waktu pembelajaran online sesuai dengan } \\
\text { kebutuhan mahasiswa }\end{array}$ & $32,1 \%$ & $67,9 \%$ \\
\hline 3 & $\begin{array}{l}\text { Dosen-dosen memberikan feedback dalam diskusi } \\
\text { online }\end{array}$ & $81,1 \%$ & $18,9 \%$ \\
\hline 4 & $\begin{array}{l}\text { Jaringan internet stabil ketika pembelajaran online } \\
\text { berlangsung }\end{array}$ & $47,2 \%$ & $52,8 \%$ \\
\hline 5 & $\begin{array}{l}\text { Lingkungan tempat tinggal mendukung proses } \\
\text { pembelajaran secara online }\end{array}$ & $43,4 \%$ & $56,6 \%$ \\
\hline 6 & $\begin{array}{l}\text { Kuota internet memadai untuk melakukan } \\
\text { pembelajaran secara online }\end{array}$ & $41,5 \%$ & $58,5 \%$ \\
\hline 7 & $\begin{array}{l}\text { Interaksi antara mahasiswa efektif selama } \\
\text { pembelajaran online }\end{array}$ & $30,2 \%$ & $69,8 \%$ \\
\hline 8 & $\begin{array}{l}\text { Mahasiswa mampu beradaptasi terhadap } \\
\text { pembelajaran online }\end{array}$ & $71,2 \%$ & $28,8 \%$ \\
\hline
\end{tabular}

Pada tabel 3 dapat dijelaskan bahwa terkait efektivitas proses perkuliahan, terdapat 27 orang mahasiswa atau 50,9\% menjawab bahwa materi yang disampaikan oleh dosen susah untuk dipahami. Hal serupa juga terjadi terkait durasi waktu pembelajaran secara online yang menurut responden sangat tidak efektif. Hal ini dapat dilihat dari persentase respon angket yang menunjukkan hanya 32,1\% mahasiswa yang menjawab "Ya" 
terhadap pertanyaan terkait. Sedangkan $67,9 \%$ diantaranya menjawab "Tidak". Permasalahan lain yang timbul terkait efektivitas proses belajar mengajar ialah feedback yang diberikan oleh dosen terhadap mahasiswa. Terdapat $18,9 \%$ atau 10 orang mahasiswa yang menjawab "Ya" dan $81,9 \%$ atau 43 orang mahasiswa yang menjawab "Tidak".

Faktor eksternal terkait kesulitan belajar yang dialami oleh mahasiswa adalah faktor- faktor penyebab terjadinya kesulitan belajar yang berasal dari luar seperti kendala jaringan, kuota, lingkungan tempat tinggal dan juga interaksi antar sesama mahasiswa ketika pembelajaran secara online sedang berlangsung. Sesuai hasil respon mahasiswa terhadap angket yang diberikan terkait beberapa faktor kesulitan dalam pembelajaran online, terdapat 28 dari 53 responden atau 52,8\% yang memberikan jawaban "Tidak" terkait kestabilan jaringan internet ketika pembelajaran online berlangsung, dan 47,2\% diantaranya menjawab "Ya". Lingkungan tempat tinggal juga mempengaruhi proses perkuliahan mahasiswa pendidikan matematika FKIP Universitas Mataram. Hal ini terlihat dari respon mahasiswa pada angket yakni sebanyak 56,6\% menjawab "Tidak" dan 43,4\% lainnya menjawab "Ya". Selanjutnya mengenai Kuota Internet yang digunakanan selama perkuliahan secara online responden menjawab sebanyak 58,5\% dari responden mengalami kendala terkait penggunaan kuota internet. Interaksi antara mahasiswa selama pembelajaran online juga dinilai kurang efektif, hal ini berdasarkan hasil survei yang menunjukkan persentase yang cukup tinggi yakni sebesar 69,8\% responden menjawab "Tidak" dan hanya 30,2\% saja yang menjawab "Ya".

Perubahan model perkuliahan dari yang sebelumnya langsung bertatap muka di kelas menuju pembelajaran secara online memiliki dampak terhadap mahasiswa. Tak terkecuali mahasiswa pendidikan Matematika FKIP Universitas Mataram. Kesiapan mahasiswa terhadap model pembelajaran secara online bisa dikatakan cukup baik. Berdasarkan hasil survei yang dilakukan sebanyak 71,2\% menjawab "Ya" dan hanya $28,8 \%$ saja yang menjawab "Tidak". Berdasarkan hasil Penelitian yang telah dilaksanakan peneliti menemukan bahwa mahasiswa pendidikan matematika FKIP Universitas Mataram mengalami kesulitan belajar diakibatkan oleh kondisi jaringan internet yang tidak stabil diakibatkan oleh letak geografis tempat tinggal mahasiswa yang berada di daerah yang kurang memungkinkan untuk mendapatkan sinyal internet yang baik dalam proses perkuliahan online. Hal ini dapat dilihat dalam diagram lingkaran pada gambar 1 .

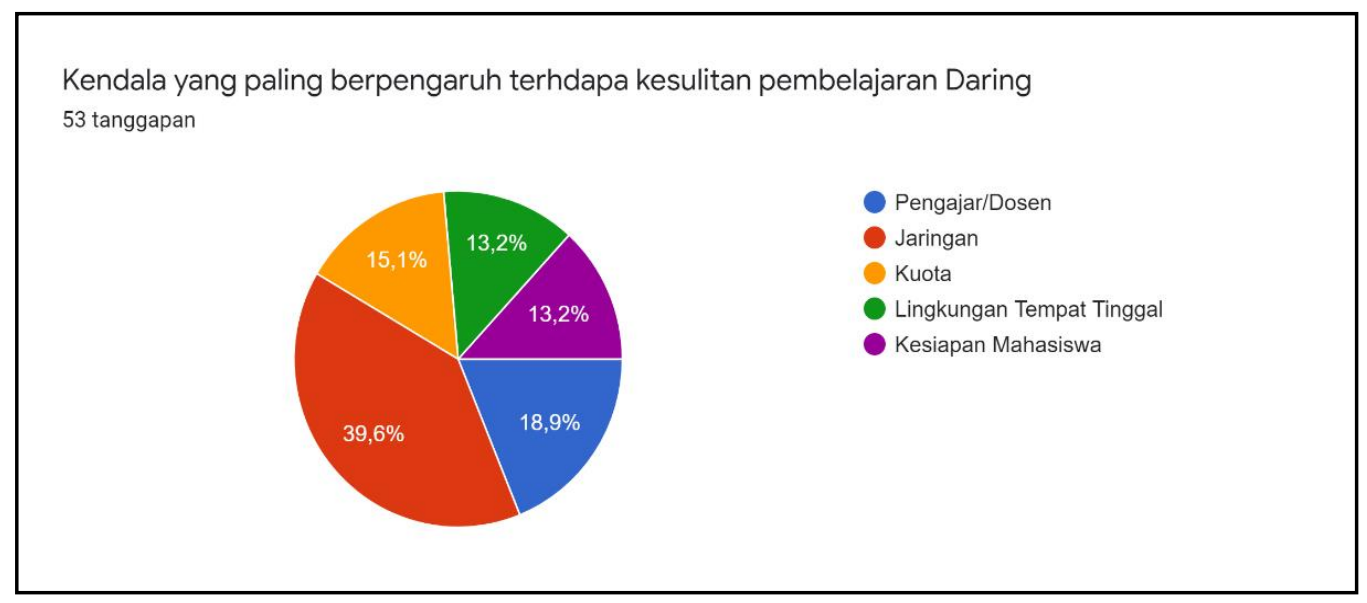

Gambar 2 : Presentase Kendala Kesulitan Belajar Mahasiswa

Dari tabel 3 dan gambar 2 di atas dapat dilihat bahwa permasalahan yang dialami sebagian mahasiswa ialah kurangnya pemahaman terkait materi ajar yang disampaikan oleh dosen. Mahasiswa yang mengalami hambatan dalam proses perkuliahan akan mendapatkan hasil pembelajaran yang kurang optimal. Hal ini juga sejalan dengan hasil penelitian dari Kusumaningrum \& Wijayanto (2020, p. 139) yang menyebutkan bahwa dari 100 responden yang diteliti terdapat 69 responden mengalami kesulitan dalam memahami materi. Lebih lanjut dijelaskan bahwa dari adanya kesulitan saat memahami materi, berdasarkan hasil angket, responden menginginkan adanya video pembelajaran yang menjelaskan materi pada setiap pertemuan sehingga video 
tersebut dapat diputar kembali jika mahasiswa belum mengerti. Hasil penelitian menarik ditemukan oleh Makur et al. (2021, p. 9) bahwa dengan perkuliahan secara online menyebabkan $80 \%$ mahasiswa terbiasa mencari jawaban dan tugas-tugas yang diberikan dosen dari internet. Sedangkan menurut Mallet dalam Noviyanti (2011, p. 86) menyebutkan bahwa tugas-tugas secara online dapat diberikan kepada mahasiswa untuk menilai keaktifan berdiskusi dan kemampuan komunikasi matematis mahasiswa.

Faktor lain yang mempengaruhi kesulitan mahasiswa dalam perkuliahan secara online adalah durasi pembelajaran daring yang tidak efektif. Hal ini terlihat dari hasil respon mahasiswa terkait permasalahan tersebut yakni sebanyak 67,9\% yang menjawab bahwa durasi pembelajaran tidak efektif. Tetapi ada juga mahasiswa yang aktif mengerjakan tugas-tugas yang diberikan secara online. Sedangkan hasil penelitian dari Mustakim (2020, p. 10) menunjukkan bahwa hanya $10 \%$ responden menjawab perkuliahan secara online tidak efektif. Selanjutnya hasil penelitian ini menyarakan untuk meningkatkan efektivitas perkuliahan secara online sebaiknya, perkuliahan dilaksanakan secara video call, penjelasan materi perkuliahan yang ringkas dan mengurangi pengiriman materi dalam format video berat untuk menghemat kuota.

Berdasarkan hasil angket yang diterima terkait permasalahan seputar efektivitas pembelajaran ditemukan permasalahan terkait timbal balik atau feedback yang diberikan oleh dosen kepada mahasiswa ketika perkuliahan berlangsung. Persentase responden yang menjawab "Tidak" adalah 18,9\% sedangkan yang menjawab "Ya" sebanyak $81,1 \%$. Walaupun persentasenya kecil, namun hal ini tetap menjadi permasalahan yang tidak bisa dipandang sebelah mata. Menurut Sabriani (2012, p. 41) dengan pemberian tugas terstruktur dengan disertai feedback pada pembelajaran dapat meningkatkan motivasi dan hasil belajar peserta didik.

Faktor lain penyebab terjadinya kesulitan perkuliahan secara online adalah kondisi jaringan internet yang tidak stabil ketika proses perkuliahan sedang berlangsung. Berdasarkan hasil angket yang didapatkan menunjukkan bahwa 52,8\% responden mengeluhkan kondisi jaringan internet yang tidak stabil. Hal ini dikarenakan letak geografis tempat tinggal mahasiswa yang berada di pelosok tidak mendukung kestabilan jaringan internet. Perkuliahan berbasis online tentu memerlukan jumlah kuota yang tidak sedikit. Terutama untuk beberapa platform pembelajaran berbasis video seperti Zoom sangat memerlukan kuota yang besar. Kondisi keterbatasan kuota seperti ini yang menjadi salah satu faktor kesulitan yang dialami mahasiswa pendidikan matematika FKIP Universitas Mataram. Hal ini ditunjukkan dengan hasil angket yang dimana 58,5\% responden menjawab "Tidak" atau menjawab kuota yang mereka butuhkan untuk perkuliahan secara online tidak cukup. Hasil temuan ini juga didukung oleh hasil penelitian Annur \& Hermansyah (2020, p. 197) yang menyebutkan bahwa banyak diantara mahasiswa yang harus meminjam laptop temannya untuk mengikuti perkuliahan online. Pemanfaatan smartphone menggantikan peran komputer atau laptop, cukup membantu mahasiswa. Sedangkan, kendala kuota internet yang kurang mencukupi juga mempersulit mereka. Banyak dari mereka yang harus datang ke cafe-cafe atau bahkan ke kampus hanya sekedar untuk dapat tersambung dengan sinyal wifi. Dimasa pandemi COVID-19 seperti saat ini, tentu hal ini menyulitkan dan mengancam kesehatan mereka. Namun, permasalahan kuota ini telah mampu dianulir oleh pemerintah dengan program dari Kementerian Pendidikan dan Kebudayaan (Kemendikbud) RI dengan menyalurkan bantuan kuota internet gratis bagi pelajar, mahasiswa, guru dan dosen mulai September 2020 (http://kuotabelajar.kemdikbud.go.id/). Bantuan kuota gratis ini ini akan diberikan selama jangka waktu 4 bulan. Besaran kuota internetnya pun berbeda-beda bagi setiap penerima.

Dalam proses belajar mengajar matematika sebaiknya membantu peserta didik mengkonstruksi pengetahuan melalui proses. Hal ini sejalan dengan yang diungkapkan oleh Bruner bahwa pengetahuan adalah suatu proses bukan produk. Proses tersebut dimulai dengan pengalaman, sedangkan pengetahuan dibangun dari pengalaman. Oleh karena itu peserta didik diberi kesempatan untuk mengkonstruksi sendiri pengetahuan yang mereka miliki, karena dengan memberikan kesempatan kepada peserta didik merupakan suatu strategi agar peserta didik dapat saling berinteraksi melalui kelompok belajarnya. Menurut teori yang dikemukan oleh Piaget, peserta didik sebaiknya secara aktif berinteraksi dengan lingkungan belajarnya supaya dapat 
membantu mengkonstruksi pemahaman yang lebih tinggi.(Afifah, 2012, p. 145). Namun kondisi seperti ini bertolak belakang dengan yang terjadi saat dilaksanakan perkuliahan secara online. Berdasarkan hasil pada angket yang telah di jawab oleh responden, peneliti menemukan bahwa 69,8\% responden menjawab "Tidak" pada pertanyaan mengenai keefektifan interaksi antara sesama mahasiswa selama proses pembelajaran online berlangsung. Hal yang positif dari hasil penelitian ini adalah berdasarkan hasil angket menunjukkan bahwa dari segi kesiapan mahasiswa pendidikan FKIP Universitas Mataram selama pembelajaran online terbilang cukup baik yakni sebanyak 71,2\% menjawab "Ya" pada pertanyaan mengenai kesiapan mereka dalam perubahan model pembelajaran dari yang sebelumnya bertatap muka secara langsung menuju sistem pembelajaran online.

Dari berbagai kendala yang sudah dibahas di atas, kendala yang paling berpengaruh terhadap kesulitan belajar mahasiswa pendidikan matematika FKIP Univeritas Mataram ialah kendala jaringan dengan presentase terbesar sebesar 39,6\%, disusul oleh pengaruh dari tenaga pengajar atau dosen yakni sebesar 18,9\%, kendala yang diakibatkan oleh ketersedian kuota sebesar $15,1 \%$, faktor kesiapan mahasiswa dan lingkungan tempat tinggal mahasiswa masing-masing sebesar $13,2 \%$. Seperti halnya kuota yang terbatas, ini harus diantisipasi oleh responden maupun istitusi. Institusi dapat menerapkan beberapa langkah strategis seperti halnya menyiapkan dan menyediakan aplikasi e-learning yang rendah kuota (tidak memerlukan kuota internet besar) dalam mengaksesnya. Temuan dalam penelitian ini hanya terbatas pada kesulitan belajar mahasiswa secara teknis pelaksanaan pembelajaran online pada masa pandemi covid-19, bukan kesulitan dalam hal memahami fakta, konsep dan prinsip dalam matematika. Harapan bagi pendidik berkaitan dengan pembelajaran secara online adalah, setelah kondisi kembali normal ataupun wabah Covid-19 sudah berakhir, disamping pembelajaran di kelas maka pembelajaran daring tetap bisa dilaksanakan untuk melatih keterampilan dosen dan mahasiswa pada era industri 4.0. (Anugrahana, 2020, p. 287). Pembelajaran secara online dapat sebagai alternatif dosen dalam menerapkan model-model pembelajaran. Hal ini bertujuan untuk menambah ilmu dan mengaplikasikan penggunaan kemajuan teknologi dengan baik dan benar.

Revolusi industri 4.0 yang sedang berlangsung saat ini sedikit banyak berdampak di berbagai bidang, salah satunya bidang pendidikan, dan Internet of Things (IOT) menandai adanya revolusi industri tersebut, oleh karena itu tidak dapat dipungkiri bahwa bidang pendidikan harus dapat beradaptasi terhadap perkembangan teknologi dan sejenisnya supaya sistem pembelajarannya tidak akan ketinggalan zaman, maka pembelajaran tidak harus tatap muka. Pembelajaran online kini menjadi solusi penerapan Internet of Things di bidang pendidikan. Namun yang menjadi pertanyaan saat ini adalah apakah pembelajaran online berhasil menggantikan pembelajaran di kelas, atau faktor apa saja yang harus diperhatikan agar pembelajaran online dapat dioperasikan sesuai keinginan pengguna, dan apakah sektor pendidikan benar-benar siap menghadapi revolusi industri 4.0 .

\section{KESIMPULAN}

Kesimpulan penelitian ini adalah terdapat berbagai macam kesulitan yang dihadapi oleh mahasiswa Pendidikan Matematika FKIP Universitas Mataram selama pembelajaran secara online. Adapun kesulitan dalam proses pembelajaran online yang di alami oleh mahasiswa terletak pada efektifitas proses belajar mengajar dan juga faktor kendala teknis seperti jaringan internet yang tidak stabil, kuota yang terbatas, faktor lingkungan tempat tinggal mahasiswa dan juga Interaksi yang minim ketika proses pembelajaran online berlangsung.

\section{DAFTAR PUSTAKA}

Afifah, D. S. N. (2012). Interaksi Belajar Matematika Siswa Dalam Pembelajaran Kooperatif Tipe STAD. 
PEDAGOGIA, 1(2), 145-151.

Anggrawan, A. (2019). Analisis Deskriptif Hasil Belajar Pembelajaran Tatap Muka dan Pembelajaran Daring Menurut Gaya Belajar Mahasiswa. Jurnal MATRIK, 18(2), 339-346.

Annur, M. F., \& Hermansyah. (2020). Analisis kesulitan mahasiswa Pendidikan Matematika Dalam Pembelajaran Daring Pada Masa Pandemi COVID-19. Jurnal Kajian, Pnelitian Dan Pengembangan Kependidikan, 6356, 195-201. https://doi.org/Prefix DOI: 10.31764

Anugrahana, A. (2020). Hambatan, Solusi dan Harapan: Pembelajaran Daring Selama Masa Pandemi Covid19 Oleh Guru Sekolah Dasar. Scholaria: Jurnal Pendidikan Dan Kebudayaan, 10(3), 282-289. https://doi.org/10.24246/j.js.2020.v10.i3.p282-289

Darmalaksana, W., Hambali, R. Y. A., Masrur, A., \& Muhlas. (2020). Analisis Pembelajaran Online Masa WFH Pandemic Covid-19 sebagai Tantangan Pemimpin Digital Abad 21. Karya Tulis Ilmiah (KTI) Masa Work From Home (WFH) Covid-19 UIN Sunan Gunung Djati Bandung Tahun 2020, 1(1), 1-12.

Febriaty, H. (2018). Pengaruh Gaya Hidup dan Literasi Keuangan Terhadap Perilaku Konsumtif Mahasiswa. Jurnal Riset Sains Manajemen, 2(3), 103-110. https://doi.org/10.5281/zenodo.1410873

Firman, F., \& Rahayu, S. (2020). Pembelajaran Online di Tengah Pandemi Covid-19. Indonesian Journal of Educational Science (IJES), 2(2), 81-89. https://doi.org/10.31605/ijes.v2i2.659

Fitriyani, Y., Fauzi, I., \& Sari, M. Z. (2020). Motivasi Belajar Mahasiswa Pada Pembelajaran Daring Selama Pandemik Covid-19 Yani. Jurnal Kependidikan: Jurnal Hasil Penelitian Dan Kajian Kepustakaan Di Bidang Pendidikan, Pengajaran Dan Pembelajaran, 6(2), 165-175. http://digilib.uinsgd.ac.id/id/eprint/30565

Hartanto, W. (2016). Penggunaan E-Learning Sebagai Media Pembelajaran. JURNAL PENDIDIKAN EKONOMI, 10(1). https://jurnal.unej.ac.id/index.php/JPE/article/view/3438

Hasanah, A., Sri Lestari, A., Rahman, A. Y., \& Danil, Y. I. (2020). Analisis Aktivitas Belajar Daring Mahasiswa Pada Pandemi COVID-19. Karya Tulis Ilmiah (KTI) Masa Work From Home (WFH) Covid19 UIN Sunan Gunung Djati Bandung Tahun 2020, 4-8. http://digilib.uinsgd.ac.id/id/eprint/30565

Kumalasari, A., \& Sugiman. (2015). Analisis Kesulitan Belajar Mahasiswa Pada Mata Kuliah Kapita Selekta Matematika Sekolah Menengah. JURNAL RISET PENDIDIKAN MATEMATIKA, 2(1), 16-27. http://journal.uny.ac.id/index.php/jrpm/index

Kusumaningrum, B., \& Wijayanto, Z. (2020). Apakah Pembelajaran Matematika Secara Daring Efektif? (Studi Kasus pada Pembelajaran Selama Masa Pandemi Covid-19). Kreano, Jurnal Matematika KreatifInovatif, 11(2), 139-146. https://journal.unnes.ac.id/nju/index.php/kreano/article/view/25029

Makur, A. P., Jehadus, E., Fedi, S., Jelatu, S., Murni, V., \& Raga, P. (2021). Kemandirian Belajar Mahasiswa dalam Pembelajaran Jarak Jauh Selama Masa Pandemi Mosharafa : Jurnal Pendidikan Matematika Mosharafa: Jurnal Pendidikan Matematika. Mosharafa: Jurnal Pendidikan Matematika, 10(1), 1. https://journal.institutpendidikan.ac.id/index.php/mosharafa/article/view/mv10n1

Marbun, P. (2021). Disain Pembelajaran Online Pada Era Dan Pasca Covid-19. CSRID (Computer Science Research and Its Development Journal), 12(2), 129. https://doi.org/10.22303/csrid.12.2.2020.129-142

Maulana, H. A. (2021). Persepsi Mahasiswa terhadap Pembelajaran Daring di Pendidikan Tinggi Vokasi : Studi Perbandingan antara Penggunaan Google Classroom dan Zoom Meeting. Edukatif: Jurnal Ilmu Pendidikan, 3(1), 188-195. https://doi.org/: https://doi.org/10.31004/edukatif.v3i1.259 Copyright

Monariska, E.-. (2019). Analisis kesulitan belajar mahasiswa pada materi integral. Jurnal Analisa, 5(1), 9-19. https://doi.org/10.15575/ja.v5i1.4181

Mustakim, M. (2020). Efektivitas Pembelajaran Daring Menggunakan Media Online Selama Pandemi Covid19 Pada Mata Pelajaran Matematika. Al Asma: Journal of Islamic Education, 2(1), 1. https://doi.org/10.24252/asma.v2i1.13646 
910 Analisis Kesulitan Belajar Mahasiswa Secara Online (E-Learning) Selama Masa Pandemi Covid-19Muhammad Turmuzi, Arifman S. Haji Dasing, Baidowi, Junaidi

DOI: https://doi.org/10.31004/edukatif.v3i3.482

Noveandini, R., \& Wulandri, M. S. (2010). Pemanfaatan Media Pembelajaran Secara Online ( E-Learning ) Bagi Wanita Karir Dalam Upaya Meningkatkan Efektivitas Dan Fleksibilitas Pemantauan Kegiatan Belajar Anak Siswa / I Sekolah Dasar. Seminar Nasional Aplikasi Teknologi Informasi, 2010(Snati), 7174.

Noviati, W. (2020). Kesulitan Pembelajaran Online Mahasiswa Pendidikan Biologi di Tengah Pandemi Covid19. Jurnal Pendidikan MIPA, 10(januari 2020), 1-11. https://doi.org/https://doi.org/10.37630/jpm.v10i1.258

Noviyanti, M. (2011). Pengaruh Motivasi dan Keterampilan Berkomunikasi Terhadap Prestasi Belajar Mahasiswa Pada Tutorial Online Berbasis Pendekatan Kontekstual Pada Matakuliah Statistika Pendidikan. Jurnal Pendidikan, 12(02), 80-88.

Pujiasih, E. (2020). Membangun Generasi Emas Dengan Variasi Pembelajaran Online Di Masa Pandemi Covid-19 Building a Golden Generation By Applying Various Online Learning in the Pandemic of Covid-19. Ideguru: Jurnal Karya Ilmiah Guru, 5(1), 42-48. https://jurnaldikpora.jogjaprov.go.id/index.php/jurnalideguru/article/view/136

Sabriani, S. (2012). Penerapan Pemberian Tugas Terstruktur disertai Umpan Balik pada Pembelajaran Langsung untuk Meningkatkan Motivasi dan Hasil Belajar Siswa (Studi Pada Materi Pokok Struktur Atom Kelas X6 SMA Negeri Watampone). Jurnal Chemica, 13, 39-46.

Sadikin, A., \& Hamidah, A. (2020). Pembelajaran Daring di Tengah Wabah Covid-19. Biodik, 6(2), 109-119. https://doi.org/10.22437/bio.v6i2.9759

Simanjuntak, D. R., \& Harahap, M. S. (2020). PEMBELAJARAN SECARA DARING SELAMA MASA PANDEMI COVID-19. JURNAL MathEdu (Mathematic Education Journal), 3(3), 142-146. http://journal.ipts.ac.id/index.php/MathEdu

Utami, Y. P., \& Cahyono, D. A. D. (2020). Study At Home: Analisis Kesulitan Belajar Matematika Pada Proses Pembelajaran Daring. Jurnal Ilmiah Matematika Realistik, 1(1), 20-26. https://doi.org/10.33365/ji-mr.v1i1.252

Yunitasari, R., \& Hanifah, U. (2020). Pengaruh Pembelajaran Daring terhadap Minat Belajar Siswa pada Masa COVID-19. Edukatif: Jurnal Ilmu Pendidikan, 2(3), 232-243. 